\title{
CORRECTION
}

View Article Online

View Journal | View Issue

D) Check for updates

Cite this: RSC Adv., 2020, 10, 42338

DOI: 10.1039/d0ra90122a

rsc.li/rsc-advances

\section{Correction: Influence of micro/nanobubbles on clogging in drip irrigation systems}

\author{
Hao Li, ${ }^{\text {ab }}$ Hong Li, ${ }^{\text {*a }}$ Qibiao Han, ${ }^{\text {*b }}$ Xiuqiao Huang, ${ }^{\text {b Yue Jiang, }}{ }^{a}$ Hao Sun ${ }^{b}$ and Hui Li ${ }^{\text {b }}$ \\ Correction for 'Influence of micro/nanobubbles on clogging in drip irrigation systems' by Hao Li et al., RSC \\ Adv., 2020, 10, 38912-38922, DOI: 10.1039/dOra07782h
}

\section{Acknowledgements}

This research was supported by The National Key Research and Development Program of China (2017YFC0403204, 2016YFC0400202) and Central Public-Interest Scientific Institution Basal Research Fund (FIRI202001-01).

The Royal Society of Chemistry apologises for these errors and any consequent inconvenience to authors and readers. 